\title{
HIBRIDISMOS ENTRE OS SIGNOS SONOROS, VISUAIS E VERBAIS NO WEBDESIGN
}

\author{
Frederico Braida \\ Universidade Federal de Juiz de Fora (UFJF) / Pontifícia Universidade \\ Católica do Rio de Janeiro (PUC-Rio) \\ frederico.braida@ufjf.edu.br \\ Vera Lúcia Moreira dos Santos Nojima \\ Pontifícia Universidade Católica do Rio de Janeiro (PUC-Rio) \\ nojima@puc-rio.br
}

\begin{abstract}
Resumo: Este artigo é resultado de uma pesquisa, através da qual foram investigados os hibridismos entre os signos sonoros, visuais e verbais na construção da linguagem dos websites. A metodologia utilizada foi a leitura e análise semiótica de alguns sites pré-selecionados, com um especial enfoque nas matrizes da linguagem e pensamento propostas por Lucia Santaella. Ao final da pesquisa, verificou-se que os webdesigners pouco têm explorado todas as potencialidades da hipermídia (a linguagem da cultura digital) principalmente no que diz respeito à integração das matrizes sonora, visual e verbal em um único ambiente que se pretende democrático e universal.
\end{abstract}

Palavras-Chave: Webdesign. Hipermídia. Semiótica.

\begin{abstract}
This paper is a result of a research through which the hybridism between sound, visual and verbal signs in the language of websites was investigated. The methodology used was the semiotics reading and analysis of a group of sites which were previously selected with a special focus on the matrices of language and thought proposed by Lucia Santaella. At the end of the research, we verified that the web designers have not explored all the potentialities of hypermedia (the language of digital culture) mainly about the sonorous, visual and verbal integration of the matrices in an environment that intents to be democratic and universal.
\end{abstract}

Keywords: Web design. Methodology. Semiotics. 


\section{INTRODUÇÃO}

O presente artigo é resultado dos desdobramentos de parte das discussões travadas em uma pesquisa sobre as representações das cidades no meio digital, desenvolvida no Programa de Pós-Graduação em Design, da Pontifícia Universidade Católica do Rio de Janeiro, no âmbito do Grupo de Pesquisa Tríades, a qual teve por objetivo diagnosticar como os webdesigners têm explorado a linguagem hipermídia em seus projetos para websites, sobretudo no que diz respeito às hibridizações entre os signos sonoros, visuais e verbais na construção de um espaço digital hipermidiático e multissensorial, característico da contemporaneidade.

Deve-se destacar que, embora a hipermídia possibilite uma completa integração entre sons, imagens e textos em um mesmo ambiente, os resultados da pesquisa sinalizam a existência de uma grande quantidade de websites disponível na Internet que não apresenta tais articulações (tecnologicamente) viáveis. Ressalta-se, portanto, que o discurso sobre o webdesign se afasta da sua pragmática. De tal constatação, surge a seguinte pergunta: estão os webdesigners explorando todas as potencialidades da hipermídia em seus projetos para o meio digital?

Procura-se, então, neste artigo, evidenciar que os webdesigners precisam desenvolver estratégias projetuais que contemplem os hibridismos verbo-visuaissonoros, há muito já reclamados pela poesia concreta. Afinal, de acordo com Lévy (2003, p.72), "quanto mais as linguagens se enriquecem e se estendem, maiores são as possibilidades de simular, imaginar, fazer imaginar um alhures ou uma alteridade". Portanto, recursos sonoros, visuais e verbais, reunidos de forma interativa em uma interface digital, de modo a despertar sensações sinestésicas, devem ser mutuamente explorados pelos designers; caso contrário, pode-se dizer, sumariamente, que seus projetos subutilizam as características do meio digital e da linguagem com a qual os websites são construídos e trilham um percurso que segue em direção oposta àquela que o design universal buscar percorrer.

\section{HIPERMÍDIA: A LINGUAGEM DOS WEBSITES OU OS HOBRIDISMOS ENTRE SOM, IMAGEM E TEXTO}

Após os anos de 1980, com o desenvolvimento das novas tecnologias de informação e comunicação, a complexidade do campo comunicacional foi intensificada. Os computadores e, mais especificamente, as tecnologias digitais, infiltraram-se de forma tão definitiva em todos os campos da atuação humana que se pode dizer que há estabelecida uma nova forma de se ver o mundo: a digital.

De acordo com Fernandes (2004, p.7), na contemporaneidade, é totalmente alterada a condição do homem no mundo. Agora o mundo virtual e o mundo do domínio parecem integrar a complexidade de nossa existência. O homem exerce influência individual e direta e muda sua relação com o saber, aprender, apreender, memorizar, exercer. O universo digital que se apresenta primeiramente como simulação do real, na condição de virtual e expandido do natural, com inteligência própria, interativo, passa agora à condição de interlocutor.

Com a emergência do ciberespaço, o espaço virtual digital, e da comunicação mediada por computadores, signos da cibercultura, surgiu uma nova linguagem: a 
hipermídia. A hipermídia é, portanto, a linguagem do novo ambiente de comunicação, ou seja, do ciberespaço ${ }^{1}$. De acordo com Silveira (2003, p.14), o sistema de hipermídia para obter informações por meio da rede conhecida como World Wide Web (WWW) foi uma aplicação decisiva para a rápida popularização da Internet ${ }^{2}$.

Segundo Santaella (2005a, p.390), depois da digitalização, "todos campos tradicionais de produção de linguagem e processos de comunicação humanos juntaram-se na constituição da hipermídia". Assim, superada a incompatibilidade entre os suportes para os sons, para as imagens e para os textos, a palavra de ordem passou a ser "convergência" ou "hibridismo". Para a hipermídia "convergem o texto escrito (livros, periódicos científicos, jornais, revistas), o audiovisual (televisão, vídeo, cinema) e a informática (computadores e programas informáticos)" (Santaella, 2005a, p.390).

De acordo com Feldman (1995, p.4, apud Santaella, 2004b, p.48), em uma definição sucinta e precisa, hipermídia significa "a integração sem suturas de dados, textos, imagens de todas as espécies e sons dentro de um único ambiente de informação digital". O termo "hipermídia" é uma expansão da noção de "hipertexto" utilizado "para descrever uma nova forma de mídia que utiliza o poder do computador para arquivar, recuperar e distribuir informação nas formas de figuras gráficas, texto, animação, áudio, vídeo, e mesmo mundos virtuais dinâmicos" (Santaella, 2003, p.93). Segundo Costa (2005), "desenvolvimento do hipertexto, a hipermídia integra texto com imagens, vídeo e som, geralmente vinculados entre si de forma interativa". Para o autor, uma enciclopédia em CD-ROM é um exemplo clássico de hipermídia.

Segundo Landow (1994 apud Santaella, 2005, p.390), a hipermídia é "uma linguagem inaugural em um novo tipo de meio ou ambiente de informação no qual ler, perceber, escrever, pensar e sentir adquirem características inéditas". Para Laufer e Saneta (1997, apud Santaella, 2005, p.391), "do ponto de vista da linguagem e da comunicação, a hipermídia se define como acesso simultâneo a determinados textos, imagens e sons, utilizando-se uma ou mais telas eletrônicas", por isso, de acordo com Leão (2005, p.9), "o termo hipermídia designa um tipo de escritura complexa, na qual diferentes blocos de informações estão interconectados".

Cardoso (2005, p.209) menciona que "a partir de uma linguagem binária que, de tão elementar, quase desmerece a noção de linguagem, faz-se possível abranger todas as linguagens, todas as formas de expressão, veiculá-las e traduzi-las de um meio de registro para outro". Para Santaella (2005, p.389), além da universalização da linguagem, a digitalização possui, pelo menos, outros dois méritos: (1) a compressão de dados e (2) a independência da informação digital em relação ao meio de transporte. Santaella (2003, p.95; 2004, p.47-52) também apresenta quatro traços caracterizadores da hipermídia, os quais não se referem aos possíveis conteúdos, mas aos traços gerais que a configuram como linguagem: (1) o primeiro traço encontra-se na hibridização de linguagens, processos sígnicos, códigos, mídias que ela aciona e, consequentemente, na mistura de sentidos receptores, na sensorialidade global, sinestesia reverberante que ela é capaz de produzir, na medida mesma em que o receptor interage com ela, cooperando na sua realização; (2) o segundo, na capacidade de armazenar informação e, por meio da interação do receptor, transmutar-se em incontáveis versões virtuais que vão brotando na medida mesma em que o receptor se coloca em posição de coautor; (3) o terceiro é o fato de a hipermídia ter um sistema

\footnotetext{
${ }^{1}$ Cf. Santaella (2004b), em especial o capítulo 2, intitulado "O ciberespaço e sua linguagem: a hipermídia".

${ }^{2}$ De acordo com Leão (2005, p.140), "a WWW é uma rede criada a partir da tecnologia hipermidiática”.
} 
próprio de conexões e nexos, caracterizado pela descontinuidade dos nós e necessitar de mapeamento, da engenhosidade de um roteiro que possa ir sinalizando rotas de navegação do usuário; e, (4) o quarto e último, é o caráter eminentemente interativo da hipermídia.

Por essas características, pode-se, de maneira muito geral, dizer que a hipermídia é capaz aguçar três dos principais sentidos humanos ${ }^{3}$ : visão, audição e tato. Além disso, de acordo com Ferrara (2002, p.48), "através do atrito sinestésico cria-se uma produção de sentidos múltiplos que não passam [necessariamente] pelo atrito dos sentidos, mas decorrem da própria magia da imagem e da sua experiência perceptiva". Por isso, também, a hipermídia emerge como uma linguagem pertinente para a construção de signos complexos, uma vez que é capaz de aproximar-se da plenitude de sentidos que um objeto "real" pode despertar em um indivíduo.

Não se deve perder de vista que a hipermídia, potencialmente, engloba recursos tanto do hipertexto, quanto da multimídia (mídias diversas). Para Leão (2005, p.16), "o que distingue a hipermídia é a possibilidade de estabelecer conexões entre diversas mídias e entre diferentes documentos ou nós de uma rede".

\section{AS MATRIZES DA LINGUAGEM E PENSAMENTO: SONORA, VISUAL E VERBAL ${ }^{4}$}

Embora a Semiótica peirciana seja, de fato, muito abstrata, se faz necessário lembrar que ela "não é apenas uma semiótica teórica e filosófica, mas tem um amplo potencial de aplicação na área dos estudos da comunicação" (Nöth, 1998, p.95). Essa aproximação entre as teorias semióticas e teorias da comunicação se dá porque, de acordo com Joly (2005, p.33), o signo pode constituir um ato de comunicação quando é destinado intencionalmente a alguém (uma saudação, uma carta) ou fornecer informações, simplesmente porque se aprende a decifrá-lo (uma postura, um tipo de roupa, um céu cinza).

Levando-se em conta que a semiótica é a ciência da significação e de todos os tipos de signos, afirmar que as teorias semióticas $e$ suas respectivas metodologias podem ser aplicadas às linguagens das mídias mais diversas e seus respectivos processos de comunicação, desde a oralidade até o ciberespaço, é uma asserção passível de pouca discussão, chegando a constituir em um truísmo (Santaella e Nöth, 2004, p.7-8).

No entanto, como se sabe, o nível de abstração dos conceitos peircianos é muito elevado e de difícil aplicação direta a linguagens manifestas ou processos concretos de signos. Santaella (2005a) propõe, então, por meio das matrizes da linguagem e pensamento, uma extrapolação das categorias fenomenológicas universais de Peirce, expandidas na sua teoria e classificação dos signos.

\footnotetext{
${ }^{3}$ De acordo com Santaella (2005a, p.73) "há uma nítida gradação decrescente de complexidade que vai da visão para a audição, desta para o tato, deste para o olfato, e deste, enfim, para o paladar".

${ }^{4}$ A hipótese das três matrizes da linguagem e pensamento foi proposta por Lucia Santaella e está minuciosamente detalhada no livro da autora intitulado "Matrizes da linguagem e pensamento: sonora visual verbal: aplicações na hipermídia", publicado originalmente em 2001, pelas editoras Iluminuras e FAPESP. Santaella é doutora em Teoria Literária pela PUC-SP e livre-docente em Ciências da Comunicação pela USP. Ela é também autora de diversos livros, os quais trazem relevantes contribuições para os campos das artes, das comunicações, da semiótica, do webdesign, entre outros.
} 
Apesar dos inúmeros hibridismos e formas de linguagem (literatura, música, teatro, desenho, pintura, gravura, escultura, arquitetura, hipermídia etc.) que possam existir, Santaella (2005a, p.20) postula que "há apenas três matrizes de linguagem e pensamento a partir das quais se originam todos os tipos de linguagens e processos sígnicos que os seres humanos, ao longo de toda a sua história, foram capazes de produzir".

No argumento de Santaella (2005a) está a convicção de que há raízes lógicas e cognitivas específicas que determinam a constituição do verbal, do visual, do sonoro, e de toda a variedade de processos sígnicos que eles geram. Para comprovar sua hipótese, a autora procura explicitar como se dá a passagem do nível lógico e cognitivo latente para o nível de manifestação das mensagens. Santaella (2005a, p.29-30, grifos nossos) afirma que o propósito que guiou a elaboração do seu sistema classificatório

foi criar um patamar intermediário entre os conceitos peircianos $e$ as linguagens manifestas, de modo que as modalidades do verbal, visual e sonoro possam servir de mediação entre a teoria peirciana e a semiótica aplicada, funcionando como um mapa orientador muito flexível $e$ multifacetado para a leitura de processos concretos de signos: um poema, um filme, uma peça musical, um programa de televisão, um objeto sonoro, e todas as suas misturas tais como podem ocorrer na hipermídia.

De acordo com a hipótese das matrizes da linguagem e pensamento, a linguagem verbal está para a terceiridade, assim como a visual está para a secundidade e a sonora para a primeiridade. Santaella esclarece que essa idéia não se apóia apenas nas categorias de Peirce, mas também nos tipos dos signos que delas se originam.

Quadro 1 - Relações sígnicas e a correspondência com as matrizes da linguagem e pensamento

\begin{tabular}{|l|c|c|c|c|}
\hline Categorias & $\begin{array}{c}\text { Signo em } \\
\text { relação ao } \\
\text { Representamen }\end{array}$ & $\begin{array}{c}\text { Signo em } \\
\text { relação ao } \\
\text { Objeto }\end{array}$ & $\begin{array}{c}\text { Signo em } \\
\text { relação ao } \\
\text { Interpretante }\end{array}$ & $\begin{array}{c}\text { Matrizes da } \\
\text { Linguagem e } \\
\text { Pensamento }\end{array}$ \\
\hline Primeiridade & Quali-signo & Ícone & Rema & Sonora \\
\hline Secundidade & Sin-signo & Índice & Dicente & Visual \\
\hline Terceiridade & Legi-signo & Símbolo & Argumento & Verbal \\
\hline
\end{tabular}

Fonte: Braida (2007, p.65).

Segundo Santaella (2005a, p.56-57),

as matrizes da linguagem e pensamento estão sustentadas nas três classes principais de signos: o quali-signo icônico, remático para a sonoridade, o sin-signo indicial, dicente para a visualidade e o legi-signo simbólico, argumental para o discurso verbal. Entretanto, uma vez que as classes de signos são mais abstratas do que as matrizes, as classes reaparecem em distribuições diferenciadas e específicas no interior de cada matriz o que dá origem às modalidades e submodalidades exibidas por cada matriz. 
Santaella (2005a, p.53) menciona que as classificações das modalidades do discurso verbal, das formas visuais e da sintaxe sonora nasceram dentro da lógica peirciana do inclusivo e não do exclusivo. A "lógica peirciana do inclusivo" a qual a autora se refere, diz respeito ao fato de a primeiridade estar incluída na secundidade e estas duas, na terceiridade.

De fato, a sintaxe, o princípio estruturador mais primordial para o funcionamento de qualquer linguagem, alicerça a forma, assim como ambas, sintaxe e forma, alicerçam o discurso, o que significa que a forma engloba a sintaxe e o discurso engloba a forma e a sintaxe. A lógica da matriz sonora, sob a dominância da sintaxe, é mais primordial, estando na base das outras matrizes. A lógica da matriz visual, englobando a sintaxe e sob a dominância da forma, está na base da matriz verbal cuja lógica discursiva se constitui pela incorporação da sintaxe e da forma (Santaella, 2005a, p.79).

Cada matriz proposta se divide em nove modalidades, num total de 27 , além de outras submodalidades adicionais. Há, portanto, combinações e misturas, as quais não se dão apenas entre as modalidades no interior de uma mesma matriz, mas também podem se dar entre as modalidades das três matrizes. Ao apresentar as nove modalidades de cada matriz e as misturas entre elas, Santaella (2005a) pretende demonstrar quais são as bases, os princípios lógicos e as leis que regem essas misturas.

As matrizes não são puras. Não há linguagens puras. Apenas a sonoridade alcançaria um certo grau de pureza se o ouvido não fosse tátil e se não se ouvisse com o corpo todo. A visualidade, mesmo nas imagens fixas, também é tátil, além de que absorve a lógica da sintaxe, que vem do domínio sonoro. A verbal é a mais misturada de todas as linguagens, pois absorve a sintaxe do domínio sonoro e a forma do domínio visual (Santaella, 2005a, p.371).

No quadro a seguir, é apresentada a classificação das modalidades estabelecidas por Santaella. Com a ajuda deste, é possível perceber como se relacionam as três matrizes da linguagem e pensamento entre si.

\section{Matriz sonora}

1.1 Sintaxes do acaso

1.2 Sintaxe dos corpos sonoros

1.3 Sintaxes convencionais

\section{Matriz visual}

2.1 Formas não-representativas

2.2 Formas figurativas

2.3 Formas representativas
3. Matriz verbal

3.1 Descrição

3.2 Narração

3.3 Dissertação

Figura 1 - Diagrama das três matrizes e suas modalidades.

Fonte: Santaella (2005a, p.372).

Para se mapear como a linguagem hipermídia tem sido utilizada pelos designers em seus projetos de website na última década, foram escolhidos, inicialmente, um 
grupo limitado e predeterminado de sites. Foram tomados como amostra os sites oficias das capitais brasileiras, selecionados a partir de dois recortes temporais: (1) levantamento realizado entre 2006 e 2007 e (2) levantamento realizado em 2014. Analisou-se como se dão as hibridizações das matrizes sonora, visual e verbal presentes nesses sites ${ }^{5}$, a partir da classificação estabelecida por Santaella (2005). Ao final, concluiu-se que há uma evidente predominância da matriz verbal nesse tipo de site, ainda que, em alguns casos, como no site oficial da cidade do Rio de Janeiro, atualmente, haja uma tentativa de apresentar uma versão com uma maior dedicação ao discurso visual. A partir de tal constatação, ampliou-se o corpus da pesquisa e foram incluídos alguns sites jornalísticos e os grandes portais da Internet devido ao fato de as homepages desses sites apresentarem uma sintaxe semelhante.

Em tal investigação, constatou-se que a linguagem hipermídia tem sido, de certa forma, subutilizada pelos webdesigners desses sites supracitados, especialmente porque a matriz sonora recorrentemente é completamente desprezada. Em prol de uma suposta objetividade e funcionalidade técnica, abre-se mão da criação de um design capaz de despertar sensações sinestésicas, além de ser mais universal. 0 emprego das matrizes de forma pouco equilibrada denota a falta de articulação entre os sons, as imagens e os textos nos sites. Ficou evidente que o predomínio é da matriz verbal, ou seja, a quantidade de texto supera a quantidade de imagens e de sons, o que pode gerar obstáculos de acesso, o qual se pressupõe universal.

Embora o que se verifica na Internet é a predominância de sites que privilegiam a matriz verbal em detrimento das demais matrizes, é possível encontrar sites nos quais as matrizes sonora, visual e verbal estão articuladas de forma equilibrada, ou seja, em que há um verdadeiro hibridismos entre os diferentes signos. Para ressaltar essas duas realidades, são apresentados dois sites, sendo que em um deles, a matriz verbal é predominante e, no outro, os sons, as imagens e os textos estão intimamente hibridizados. Espera-se, assim, sensibilizar os webdesigners para a busca pela otimização da linguagem da hipermídia em seus projetos.

\section{Diferentes possibilidades de exploração dos hibridismos entre os signos sonoros, visuais e verbais}

Para ressaltar diferentes possibilidades de articulação entre as matrizes sonora, visual e verbal em um projeto de website, foram selecionados como objetos de análise e comparação dois sites sobre a cidade do Rio de Janeiro ${ }^{6}$. Eles são, na verdade, duas representações de uma mesma cidade.

O primeiro site foi desenvolvido para o projeto intitulado MyCity, a primeira exposição mundial de citywebdesign, exibida de dezembro de 1999 a março de 2000, no Centro Cultural Banco do Brasil (CCBB), no Rio de Janeiro, Brasil. O segundo é o Portal da Prefeitura da Cidade do Rio de Janeiro, um site governamental, o site oficial da capital fluminense. O primeiro está disponível em <http://www.mycity.com.br> e o segundo pode ser encontrado no seguinte endereço eletrônico: <http://www.rio.rj.gov.br>. Para esse segundo site, optou-se pela comparação entre

\footnotetext{
${ }^{5}$ Parte dessas análises foram apresentadas na dissertação de mestrado do autor. Deve-se acrescentar que as análises dizem respeito somente à homepage dos sites.

${ }^{6}$ Anteriormente, em dois artigos distintos, já foram apresentadas as análises dos sites supracitados de forma individualizada, à luz da semiótica e, mais especificamente, das matrizes da linguagem e pensamento. Cabe, agora, colocar tais representações lado a lado e evidenciar as semelhanças e as diferenças.
} 
dois recortes temporais distintos: uma versão de 2006, em que havia o predomínio da matriz verbal e uma versão de 2014 , em que já se verifica o predomínio da matriz visual na homepage, embora quando acessado o link <http://www.rio.rj.gov.br/home>, a estrutura sintática permanece praticamente a mesma daquela de 2006, cujo predomínio é da matriz verbal.

\subsection{Rio de Janeiro do Projeto Mycity, <http://www.mycity.com.br>}

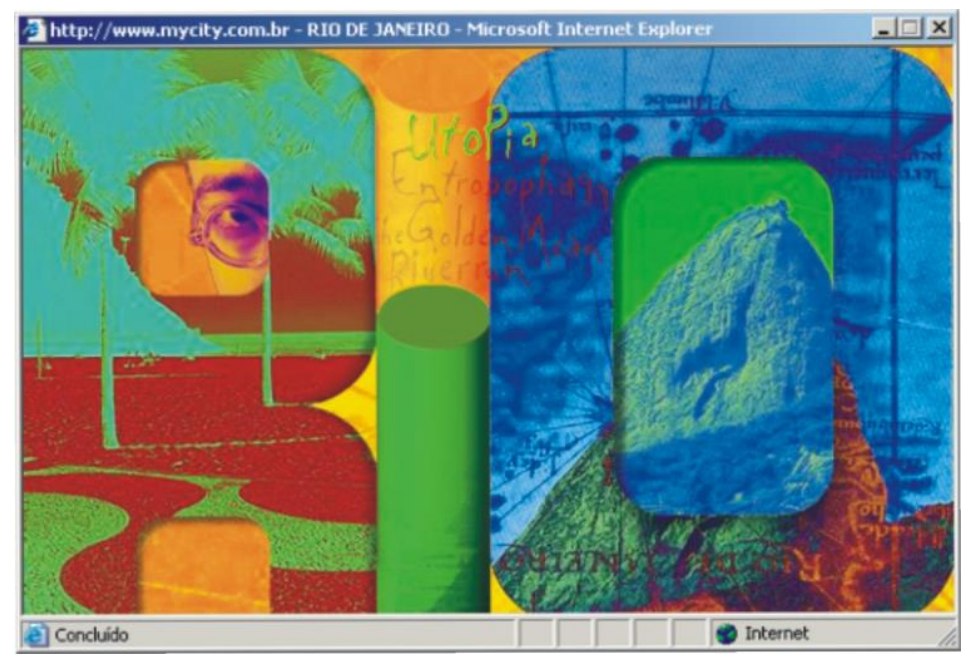

Figura 2 - Menu principal do site da cidade do Rio de Janeiro do projeto MyCity.

Disponível em: <http://www.mycity.com.br>. Acesso em 5 fev. 2014.

A linguagem utilizada nesta representação pode ser considerada como resultado de uma mistura equilibrada das três matrizes da linguagem e pensamento: sonora, visual e verbal. É interessante perceber que não há somente misturas entre as matrizes, mas, também, entre as modalidades dentro das próprias matrizes. A matriz sonora é muito importante para a composição simbólica do site. Há sons de instrumentos musicais relacionados ao samba, signo do Rio de Janeiro. Há vozes que podem ser consideradas como "voz over", caracterizada pelo emissor ausente.

Ao eleger o link "Utopia", por exemplo, aparece uma vista panorâmica da cidade, modelada em 3D, com ferramentas computacionais. Os sons da natureza, muito simbólico para a imagem urbana brasileira, acompanha a paisagem. A topografia acidentada (característica da cidade) também é muito destacada.

Esse é um site que possibilita várias reconstruções da cidade. As possibilidades de ver imagens da cidade são várias. O usuário pode imergir no site e conhecer características do cotidiano carioca, de forma bastante lúdica. O som encontra-se completamente imbricado com o texto e a imagem. E a relação entre eles é de complementação. Verifica-se, de fato, a constituição de um objeto híbrido, cujas matrizes sonora, visual e verbal encontram-se equilibradas.

\subsection{Portal da Prefeitura da Cidade do Rio de Janeiro, <http://www.rio.rj.gov.br>}

Em geral, os sites oficiais das cidades são criados com intenções políticas, administrativas e estão voltados para o marketing urbano. Neles, podem ser encontradas imagens criadas pela municipalidade, os desejos e os planos do governo para a cidade. Também o site da cidade do Rio de Janeiro é predominantemente um espaço informativo. Em especial a versão de 2006 apresentava uma aparência e uma 
composição formal muito próxima daquela recorrente nos sites de jornais e notícias, sobretudo por adotar uma linguagem referencial e denotativa. As imagens e as palavras eram inseridas em uma quadrícula pouco flexível. As imagens, quando presentes, quase sempre ilustravam os textos, ou seja, falavam muito pouco sobre si mesmas.

Já na versão atual, que pode ser considerada como uma homepage de abertura, embora as frases permaneçam curtas e diretas, há um maior apelo para o discurso visual, seguindo o paradigma instaurado pela interface do sistema operacional Windows8.
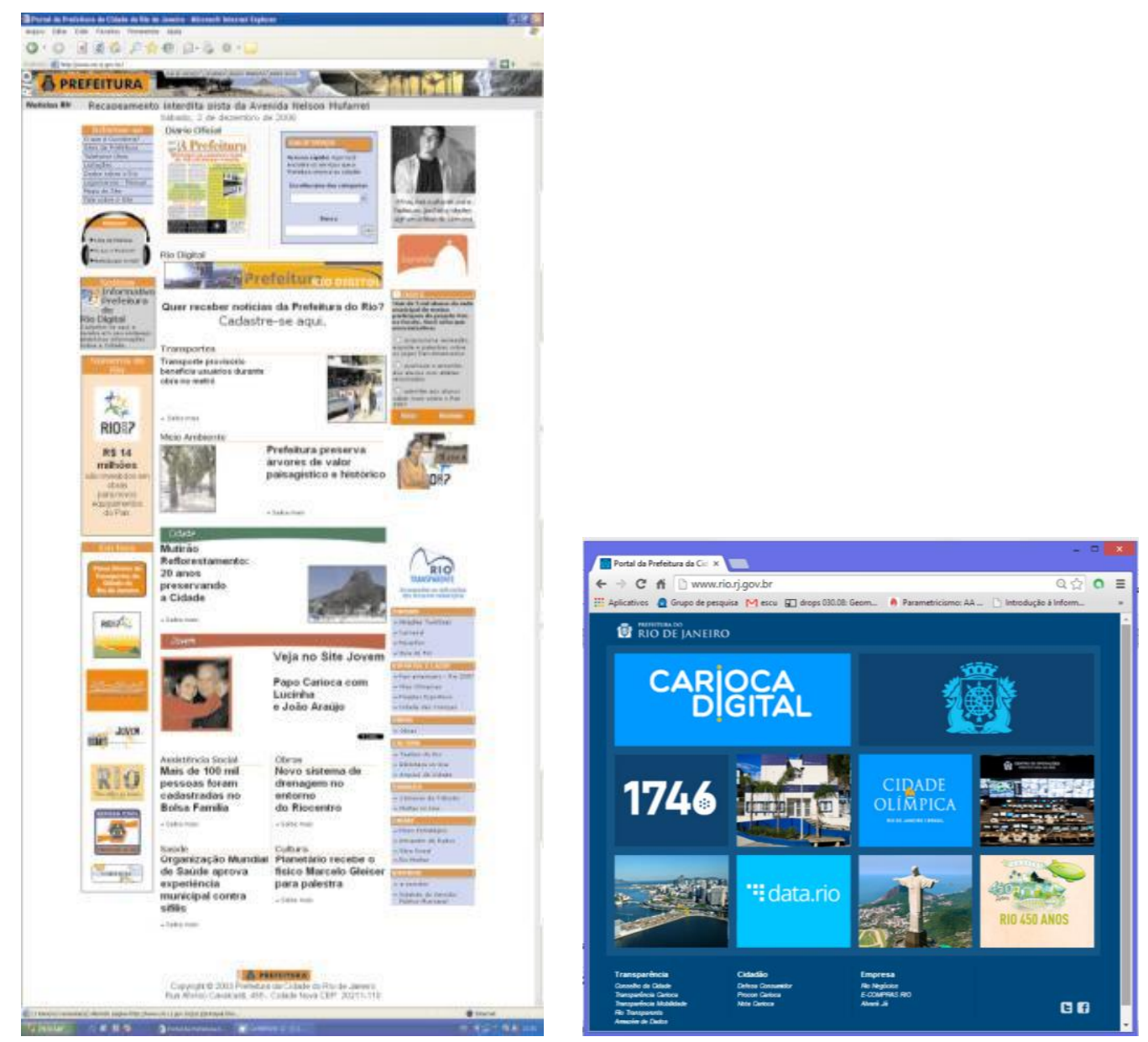

Figura 3 - Homepage do Portal da Prefeitura da Cidade do Rio de Janeiro.

Disponível em: <http://www.rio.rj.gov.br>. Acesso em: 2 dez. 2006 e 26 abr. 2014.

Com relação às matrizes da linguagem e pensamento, pode-se dizer que há, nitidamente, o predomínio da matriz verbal na versão de 2006 e da matriz visual na versão atual. No entanto, deve-se considerar que o conteúdo pleno do Portal da cidade do Rio de Janeiro encontra-se em <http://www.rio.rj.gov.br/home>, portanto é esse endereço que deve ser considerado. 


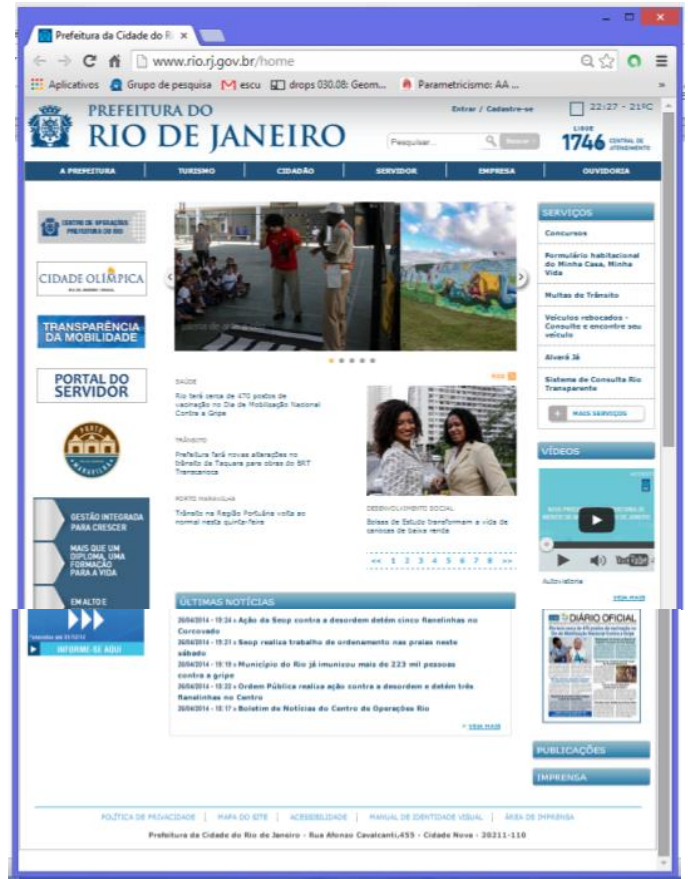

Figura 4 - Portal da Prefeitura da Cidade do Rio de Janeiro.

Disponível em: <http://www.rio.rj.gov.br/home>. Acesso em: 26 abr. 2014.

Segundo Santaella (2005, p.401), as hipermídias do tipo enciclopédico são predominantemente verbais. Pode-se acrescentar que os sites informativos também carregam a predominância da matriz verbal. As imagens divulgadas no site oficial da cidade do Rio de Janeiro são muito parecidas com as imagens dos jornais. É legítimo afirmar que o caráter das informações do site é descritivo (3.1) e, predominantemente, da narração (3.2), mais especificamente da narração sucessiva (3.2.2) por ser ela a mais típica para a maioria das notícias jornalísticas.

Constata-se que a matriz sonora nesta versão não se faz presente. Na versão de 2006, havia um som indicial que assinala o clique do mouse. Por fim, embora a matriz visual esteja presente nesse site, o discurso verbal é predominante.

\section{Conclusão}

No presente artigo, foram expostos, lado a lado, duas representações de uma mesma cidade no meio digital de tal forma que se torna evidente como em um projeto as matrizes sonora, visual e verbal encontram-se presentes de forma equilibrada e hibridizada, enquanto no outro há a predominância da matriz verbal. Conforme observado, há consideráveis diferenças entre um site que explora, ao máximo, as potencialidades da hipermídia e outro que as subutilizam.

Ao se constatar a predominância do discurso verbal nos sites investigados, acredita-se as imagens poderiam complementar os textos e fornecer subsídios para uma melhor compreensão do todo. Há casos em que as matrizes verbal e visual encontram-se tão desarticuladas (ou as imagens são tão ambíguas) que são capazes de suscitar dúvidas durante a navegação. $E$, nesse caso, para que a navegação possa

\footnotetext{
${ }^{7}$ Os números que aparecem aqui estão relacionados com a classificação das matrizes da linguagem e pensamento.
} 
prosseguir, as imagens devem ser desconsideradas e o discurso verbal deve ser tomado como verdadeiro.

Já a matriz sonora, quando não inexiste, é muito pouco explorada. O predomínio das matrizes verbal e visual sinaliza a falta de atenção dos designers com os aspectos qualitativos dos websites. Por que não complementar as matrizes verbal e visual com a matriz sonora? Por que não explorar o som? Essas são questões que ainda devem ser investigadas. São desdobramentos possíveis para esta pesquisa.

Não estão claros quais são os motivos que levam ao predomínio das matrizes verbal e visual nos websites, mas é preciso lembrar que subjacentes ao design das cidades digitais estão também as condições técnicas da própria informática. No entanto, já é possível encontrar sites acessíveis a partir de computadores não muito sofisticados conectados à Internet ou por meio smartphones que têm a matriz sonora como matriz predominante.

Finalmente, cogita-se que a mistura equilibrada das três matrizes, a exemplo dos sites do projeto MyCity, disponível em <www.mycity.com.br>, possa gerar resultados mais interessantes, além de se aproximar das práticas e soluções que contemplem o design universal. Quanto maior é o grau de hibridismo das três matrizes, maior é a complexidade atingida pela representação e, consequentemente, mais interessante torna-se o produto concebido. Quanto maior for o número de sentidos despertados pela hipermídia, mais envolvidos e imersos se encontrarão os usuários (cibercidadãos). Quanto mais imbricados estiverem as sintaxes sonoras, as formas visuais e os discursos verbais nos projetos de websites, maiores serão as possibilidades de representação das complexidades dos objetos ou referentes e, de fato, o discurso sobre a hipermídia tornar-se-á uma realidade aplicada.

\section{Agradecimentos}

Os agradecimentos são direcionados para a FAPEMIG (Fundação de Amparo a Pesquisa do Estado de Minas Gerais), pelo apoio financeiro e logístico que possibilitou a apresentação deste trabalho, e para a CAPES (Coordenação de Aperfeiçoamento de Pessoal de Nível Superior), pela bolsa do Programa Nacional de Pós Doutorado, concedida ao autor deste artigo, durante o ano de 2014.

\section{Referências}

BRAIDA, Frederico. Um estudo da semiose do design nos sites oficiais das capitais do sudeste brasileiro. (Orientadora: Dra. Vera Lúcia Nojima). Rio de Janeiro: PUC-Rio Programa de Pós-Graduação em Design, 2007.

CARDOSO, Rafael. Uma introdução à história do design. 2. ed. 1. reimp. São Paulo: Edigard Blücher, 2005.

COSTA, Carlos Irineu da. Verbete Hipermídia. In: LÉVY, Pierre. Cibercultura. 2. ed. 5. reimp. São Paulo: Editora 34, 2005. p.251-260.

FERNANDES, Patrícia de Albuquerque. Semiótica da Interatividade. Uma análise semiótica da interatividade. In: CONGRESSO BRASILEIRO DE CIÊNCIAS DA COMUNICAÇÃO, 27, 2004. Porto Alegre. Anais... São Paulo: Intercom, 2004. Disponível em: <http://reposcom.portcom.intercom.org.br/dspace/bitstream/1904/ 18142/1/R0101-1.pdf>. Acesso em: 01 jun. 2007.

FERRARA, Lucréssia D’Alessio. Design em espaços. São Paulo: Edições Rosari, 2002. 
JOLY, Martine. Introdução à análise da imagem. 9.ed. Campinas, SP: Papirus, 2005.

LEÃO, Lucia. O labirinto da hipermídia: arquitetura e navegação no ciberespaço. 3 ed. São Paulo: Iluminuras: FAPESP, 2005.

LÉVY, Pierre. 0 que é o virtual?. 6 reimp. São Paulo: Ed. 34, 2003.

NÖTH, Winfried. Panorama da semiótica: de Platão a Peirce. 2 ed. São Paulo: Annablume, 1998.

PREFEITURA DA CIDADE DO RIO DE JANEIRO. Portal da Prefeitura da Cidade do Rio de Janeiro. Disponível em: <http://www.rio.rj.gov.br>. Acesso em: 2 dez. 2006.

2014. . Disponível em: <http://www.rio.rj.gov.br/home>. Acesso em: 26 abr.

PROJETO MYCITY. Disponível em: <http://www.mycity.com.br>. Acesso em: 5 fev. 2014.

SANTAELLA, Lucia. A teoria geral dos signos: semiose e autogeneração. São Paulo: Editora Ática, 1995.

Comunicação e pesquisa: projetos para mestrado e doutorado. 2 reimp. São

Paulo: Hacker Editores, 2006.

Corpo e comunicação: sintoma da cultura. São Paulo: Paulus, 2004a.

Culturas e artes do pós-humano: da cultura das mídias à cibercultura. São Paulo: Paulus, 2003.

. Matrizes da linguagem e pensamento: sonora visual verbal: aplicações na hipermídia. 3 ed. São Paulo: Iluminuras: FAPESP, 2005a.

Navegar no ciberespaço: o perfil do leitor imersivo. São Paulo: Paulus, 2004b.

O que é semiótica. 17 reimp. São Paulo: Brasiliense, 2001.

2005b.

Por que as comunicações e as artes estão convergindo?. São Paulo: Paulus,

Semiótica aplicada. 2 reimp. São Paulo: Pioneira Thomson Learning, 2005c.

SANTAELLA, Lucia; NÖTH, Winfried. Comunicação e semiótica. São Paulo: Hacker Editores, 2004.

. Imagem: cognição, semiótica, mídia. 4 ed. São Paulo: lluminuras, 2005.

SILVEIRA, Sérgio Amadeu da. Exclusão digital: a miséria na era da informação. 1 reimp. São Paulo: Ed. Fundação Perseu Abramo, 2003. 